Annals of Warsaw University of Life Sciences - SGGW

Land Reclamation No 47 (2), 2015: 139-151

(Ann. Warsaw Univ. Life Sci. - SGGW, Land Reclam. 47 (2), 2015)

\title{
Capability and limitations in laboratory determination of stiffness parameters of soils
}

\author{
MIROSŁAW J. LIPIŃSKI, MAŁGORZATA K. WDOWSKA \\ Department of Geotechnical Engineering, Warsaw University of Life Sciences - SGGW
}

\begin{abstract}
Capability and limitations in laboratory determination of stiffness parameters of soils. The paper concerns laboratory methods for determination of soil stiffness. Major criterion for selection of analysed equipment is range of strain in which stiffness can be reliably determined. Substantially, various configurations of triaxial apparatus are referred to i.e. with standard cell and with the modified one. Additional system for internal measurement of strain is described and rational (based on test results) for use of it is presented. As to shear wave velocity measurement as a mean to obtain initial stiffness, requirements for proper measurement and interpretation was given. Finally, an approach to determine Poisson's ratio on the basis of combined results of cyclic triaxial and resonant column tests was presented.
\end{abstract}

Key words: soil stiffness parameters, small and intermediate strain range, laboratory tests

\section{INTRODUCTION}

Prediction of foundation soil behaviour under loading requires reliable evaluation of stress-strain characteristics. In the most often used elasto-plastic analysis, elastic part of the model requires proper determination and selection of soil stiffness which is represented by the following parameters: deformation modulus $(E)$, shear modulus $(G)$, bulk (volumetric strain) modulus $(K)$, Poisson's ratio $(v)$. In practice, the most often used parameters for approximation of stress-strain characteristic are deformation modulus $(E)$ and shear modulus $(G)$. It is quite obvious, that accuracy of determination of these moduli is a key issue and becomes more pronounced when dealing with stiffer soils. In such soils, deformation caused by soil structure interaction are much smaller than in soft soils, what results in more pronounced stress response against structure. The apparent conclusion is that stiffer the soil the more important is accuracy of the moduli determination in small and intermediate strain range.

The large progress in capability of stiffness parameters determination, which has been done during the last three decades, is a major premise to verify the a prevailing opinion among practicing engineers concerning nonlinearity distribution of stiffness in small and intermediate strain range. Unfortunately Polish practice within this issue is considerably delayed with respect to Western countries. In Polish geotechnical literatures little is published on non-linearity of stiffness in small and intermediate strain, and unfortunately after some 
closer inspection of those published data one can come to conclusion that they are pretty far from paradigm of perfection. For this reason the presented paper is aimed at presentation of capability and limitations of laboratory techniques for determination of stiffness in small and intermediate strain range.

It can be stated (with a certain simplification) that every laboratory technique is assigned to particular strain range. In practice, strain range relevant for serviceability limit state problems does not exceed $1 \%$. The laboratory techniques which are suitable for evaluation of stiffness in this range are:

- resonant column;

- lab set for shear and longitudinal wave velocity measurement;

- cyclic triaxial apparatus;

- triaxial apparatus with internal measurement of specimen's deformation.

Taking into account an indispensible experience required to carry out each test and interpret the obtained data properly, the above apparatuses can be considered as an advanced ones. Unfortunately, there have been a few numbers of the specified above equipment in Polish laboratories so far. It is important to emphasize that experience in doing and interpretation of these tests in Polish geotechnical laboratories varies significantly.

The paper focuses on capability of the specified techniques in determination of stiffness distribution in various strain ranges. Other important aspect of laboratory procedures (like e.g. application of back pressure to saturate a specimen) are not discussed here due to space constrains.

\section{CAPABILITY OF EQUIPMENT WITH RESPECT TO RANGE OF STRAIN}

Well controlled boundary conditions decide that the laboratory tests are much more suitable than field tests for determination of stress-strain characteristics. Known stress and strain state and well controlled drainage conditions makes possible identification of factors controlling soil behavior and quantitatively evaluate their contribution to soil response under various loading conditions. Technological jump in all branches associated with electronics which started around 30 years ago stimulated rapid development of laboratory techniques in geotechnical engineering. It particularly refers to methods for soil deformation and strain measurement. This progress made possible to identify significant nonlinearity in stiffness distribution in strain range smaller than $0.1 \%$ (Jardine et al. 1984). The major variables controlling this non-linearity are stress and strain range. The other ones, like stress history, soil structure and fabric, load rate and drainage conditions, although important, they influence to less extent stiffness distribution in small strain range. The term small strain range has acquired new meaning in comparison to research and engineering practice before 
30 years ago. In this time, strain range corresponding to value $0.1 \%$ of linear strain was considered as a small one. Presently, due to enhanced accuracy of a specimen deformation measurement in laboratory tests as well as precise field monitoring data, the small strain range "has moved" in direction of zero on strain axis by three orders of magnitude. stiffness is represented by deformation modulus. Field working range of strain corresponding to tunnels, foundations and diaphragm walls are also shown in Figure 1. It is worth to note that the most important strain range from engineering point of view does not exceed $1 \%$, and the most pronounced non-linearity of stiffness distribution corresponds to

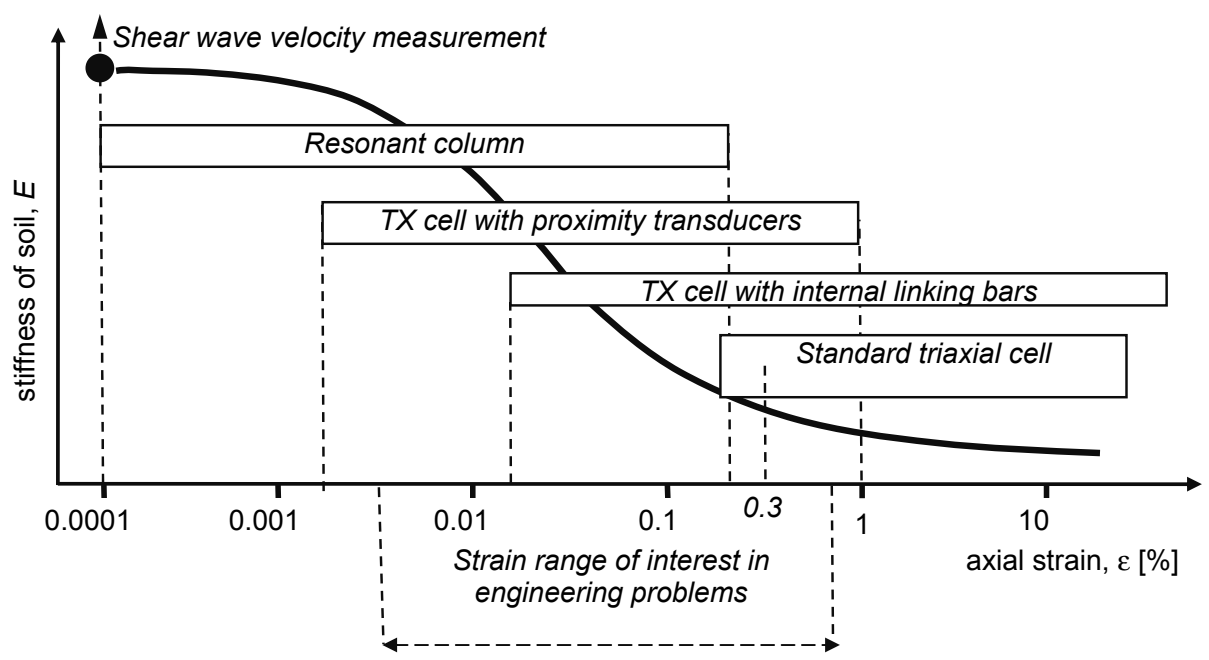

FIGURE 1. Capability of various lab apparatuses to determine stiffness with respect to strain range

Such a wide range of working strain has consequences in specialization of laboratory equipment and thus assignment of various strain ranges to particular laboratory techniques. Capability of equipment with to range of strain is shown in Figure 1 (Lipiński 2012) which is modification based on his own experience of earlier works (Atkinson and Sällfors 1991, Mair 1993). Ranges of strain in this figure are adjusted to linear strain and
$0.3 \%$. With respect to the above observations it is worth to reevaluate capability and limitations of equipment most often used in research and other geotechnical laboratories.

It is worth to note that for many years majority of laboratory devices were designed for determination of shear strength. Some of these devices, with particular reference to the most versatile triaxial test, were used to determine 
deformation characteristics. Obviously, stiffness parameters as the most useful for engineering purposes are usually determined on the basis of these characteristics. In the family of stiffness parameters the most often used in engineering application is deformation modulus $(E)$. According to Figure 1, capability of reliable evaluation of stiffness distribution various considerable, depending of equipment used. In the further part of the paper major capability and limitations of stiffness evaluation are characterized.

\section{STANDARD AND MODIFIED TRIAXIAL CELL}

As already mentioned standard triaxial apparatus has been designed for determination of shear strength, and in addition for very simply case where consolidation is isotropic and a specimen is sheared along standard stress path (vertical compression with horizontal component of stress kept constant). This fact has negative consequences for use of this apparatus for measurement of stiffness parameters, mainly due to poor capability of accurate deformation measurement. This drawback results from structural limitation of a cell, which consists of two pieces: the base and upper part with outer shell (usually made of plexiglass). In the central part of the base there is a fixed pedestal on which a specimen is set with a free cap on the top. Then the upper part is assembled, the cell is filled with water and at the end the piston rod is put inside to make a contact with a top cap. Such construction of the cell is a source of potential errors resulting from lack of alignment, not parallel planes of a specimen and joint alike connection of a top cap and a piston rod. These imperfections are described in details by Baldi et al. (1988). Each of these errors practically disqualifies the standard triaxial cell as equipment for use to determine stiffness of soil. This statement can be easy proved by a simple example. In standard triaxial test height of a specimen is around $80 \mathrm{~mm}$. An error during positioning of a piston rod, especially in the absence of horizontal stress, can change height at least $0.8 \mathrm{~mm}$ what converted to strain gives $1 \%$. Taking into account that this value is the upper bound of strain in engineering problems (Fig. 1), and the biggest non-linearity of stiffness takes place for strain smaller than $0.3 \%$, it becomes obvious that standard cell should not be used for determination of deformation parameters, because error caused in strain measurement before a test is bigger than the strain range of interest.

Another issue concerns capability of vertical stress application and accuracy in its measurement. In the standard cell, top cap and piston rod make connection through small steel ball what enables only downward application of stress (compression tests). The consequence of this is that practically the cell enables to carry out only tests with isotropic consolidation and shearing along standard stress path. The second drawback concerns error in measurement of actual vertical 
stress applied. The connection through a ball assumes that cell pressure applies isotropic stress to a specimen while additional vertical load applied through the piston rod divided by the area of a specimen makes vertical compression stress during shearing. Thus in the standard cell the vertical stress $\left(\sigma_{v}\right)$ is calculated according to the following formula

$$
\sigma_{v}=\sigma_{c}+\frac{\Delta P}{A_{p}}
$$

where:

$\sigma_{c}-$ cell pressure;

$P$ - vertical load acting on the rod;

$A_{P}$ - area of a specimen.

In order to avoid all of these problems resulting from construction of the standard cell the modified one, with internal linking bars, should be used instead. Thus, majority of problems associated with connection of a piston rod and top cap disappear since the connection is rigid as it is shown in Figure $2 b$. For comparison, the connection in standard cell is shown in Figure 2a. The differences in construction of a base of standard cell and the modified one with internal linking bars are shown in Figure 3 . The modified cell makes possible to determine precisely initial height and diameter because of easy access to a specimen when it is set up in a cell. Thus, having the reliable initial dimension the precise calculation of strain and stress can be done. Isotropic and anisotropic stress state can be imposed pre-
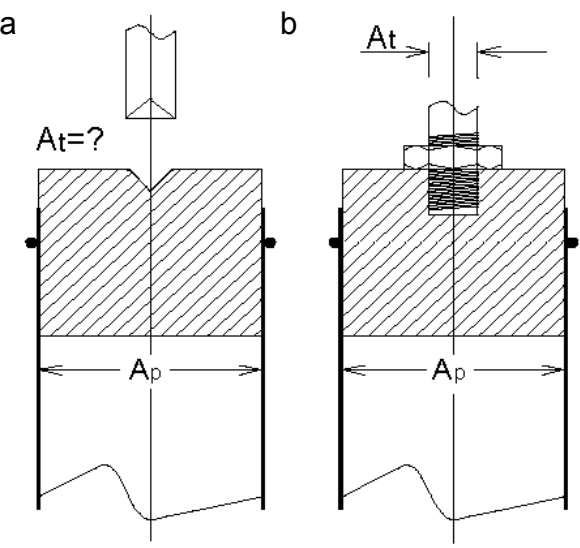

FIGURE 2. Details of connection of piston rod and the top cap: $\mathrm{a}$ - standard cell, $\mathrm{b}$ - modified cell with internal linking bars

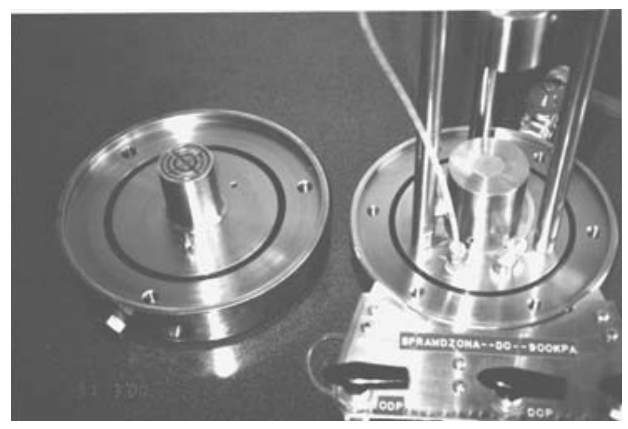

FIGURE 3. Differences in construction of the base of standard and modified triaxial cell

cisely at each stage of a test since vertical stress component can be calculated according to the following formula

$$
\sigma_{v}=\frac{P+M+F+\sigma_{c}\left(A_{p}-A_{t}\right)}{A_{p}}
$$

where:

$M$ - weight of piston rod with a top cap; $F$ - friction force on piston rod (sign depends on direction of movements); $A_{t}$ - area of piston rod. 
Minor factors (like e.g. uplift acting on top cap and piston rod) in standard tests are disregarded. Sign at friction force $(F)$ depends on direction of piston rod movement thus depends on whether a specimen is sheared in compression or extension mode. Value of friction force depends on whether a system of pressure application to a cell is pneumatic or hydraulic. In case of pneumatic system, a friction force is considerable less than in hydraulic one and there is no need to use submersible load cell inside a triaxial cell.

\section{INTERNAL MEASUREMENTS OF DEFORMATION}

At the beginning, an interest in more precise measurement of strain during triaxial tests resulted from intention of direct measurement of lateral deformation of a specimen. Indirect calculation of lateral strain, based on measured volume of water expelled during shearing, usually delivered unaccepted values of Poisson's ratio. To overcome this problem various methods of direct measurement of lateral strain were proposed. One of the most interested approach rested on use of ultrasonic method (longitudinal waves) for tracing change in specimen diameter (Barański and Wolski 1986). However to fully make the most of this approach the resolution of measurement of vertical strain should have been improved. Therefore the next stage of enhancement in stiffness measurements rests on internal measurement of deformation inside a triaxial cell. Development of these systems commenced in the mid-1980 and since that time many valuable papers on non-linear stiffness distribution appeared (Jardine et. al. 1984, Burland 1989, Jamiolkowski et al. 1994). There are many of systems of internal measurement of deformation. A comprehensive review of instrumentation for measurement of small strain of a specimen during triaxial test was presented by Scholey et al. (1995). According to the authors' experience, one of the most successful system rests on proximity transducers Kaman Insrumentation's KD-2300. This kind of system is certainly the most effective when used with cell having internal linking bars and rigid connection of top cap and a piston rod. This displacement measuring system uses inductive technology to determine the position of target relative to the system sensor. Each measuring system consist of oscillator-demodulator, sensor and a target. An AC current flows through the sensor coil, generating electromagnetic field which radiates from the sensor. As the conductive target, which is fastened to a specimen, enters this field, the sensor induces a current flow. This current produces secondary opposing field, reducing the intensity of the original. This opposing electromagnetic field results in an impedance variation in the sensor coil. This signal is then conditioned and converted to deformation which, when accounting for initial dimensions of a specimen, is changed into strain. In order to effective- 
ly measure vertical and horizontal deformation of a specimen at each stage of triaxial test (flushing, saturation, consolidation and shearing) at least six sensors are necessary. The maximum number of sensors encountered up to now is 10 . Usually, four sensors are necessary to measure deformation for vertical strain evaluation, and two sensors for horizontal component of strain. This configuration of sensors is shown in Figure 4a. Set up of sensors of horizontal deformation depends on required accuracy of deformation. 2, 3 and $6(2 \times 3)$ sensors are used for horizontal deformation. The most common configuration (2 and 3 ) are shown in Figure 4b. The set up with six sensors is the version with three sensors positioned in two horizontal planes. The advantage of three sensors solution is applied due to the fact that in case of two sensors they can not account for horizontal displacement of a specimen during shearing. There are also disadvantages of the KAMAN system. The first one is associated with possibility of leakage in sensor cables which better work in air than water environment. The second limitations refers to range of deformation measurement. Due to high resolution of the sensor (less than $2 \mu \mathrm{m}$ ), the signal is linear only in $2 \mathrm{~mm}$ range. This might cause some problems during tests on very soft soils. In such soils the deformation larger than $2 \mathrm{~mm}$ might occur at pre failure stages (usually consolidation). To account for that it is necessary to have an access to all sensors at every stage of a test. To realize that it is necessary to design a mechanical device which makes possible to change a distance between a target and a sensor by rods operated from outside the cell. This certainly complicates the construction of the cell and the procedure of the test. Those inconveniences are balanced
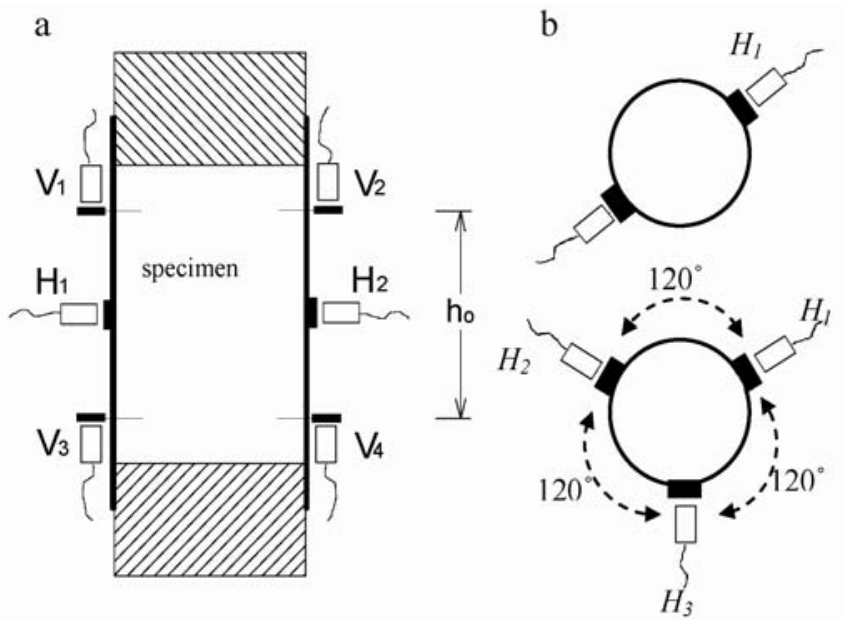

FIGURE 4. Configurations of proximity transducers positioning for internal measurement of vertical and horizontal deformations of a specimen: $a$ - side view, $b$ - top view 
by major profits in accuracy of stiffness evaluation. To confirm a clear gain in reliable strain measurement resulting from Figure 1, it is worth to compare stiffness measured internally and externally. A simple comparison of effects of these two methods of strain measurements (internal $v s$ external) on stiffness measurement is shown in Figure 5, where deformation modulus from internal $\left(E_{\text {int }}\right)$ and external $\left(E_{\text {ext }}\right)$ measurements are com- can be deduced from the Figure 5 that the difference between $\left(E_{\text {int }}\right)$ and $\left(E_{\text {ext }}\right)$ increases with stiffness and stress level and for modulus exceeding $150 \mathrm{MPa}$. The value of $E$ calculated on the basis of internal measurement is twice bigger than the one based on external measurements. It should be also emphasized that both compared moduli are determined in the cell with internal linking bars. If results from standard cell were compared

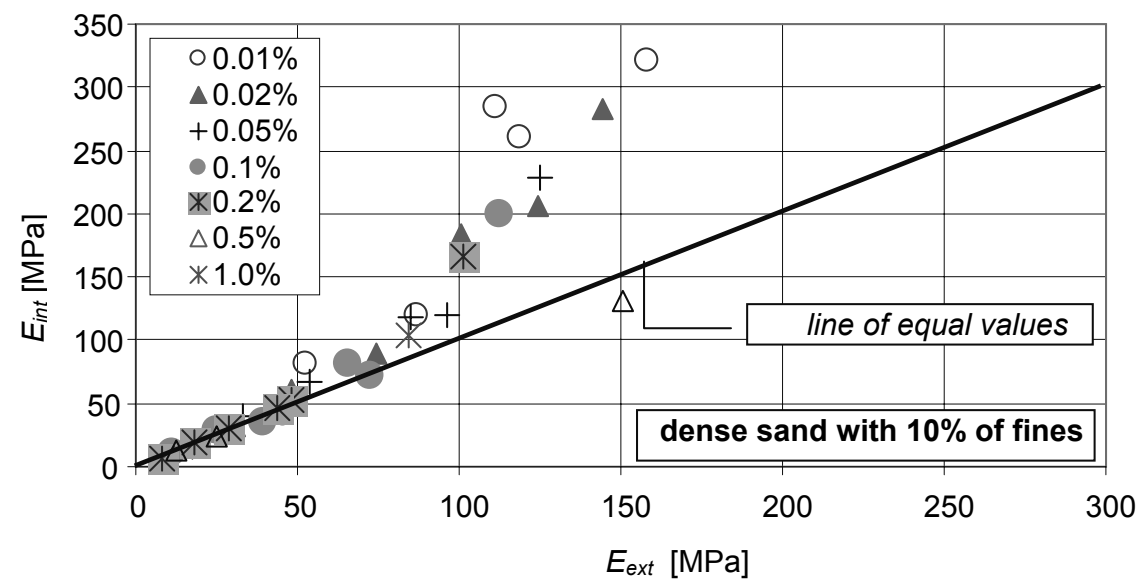

FIGURE 5. Comparison of deformation modulus based on internal and externally measurement of deformation for various strain ranges (authors' data)

pared. Due to non-linear stiffness distribution against strain, deformation modulus is compared for various strain ranges. Strain from 0.01 to $1.0 \%$ are selected since this is the range relevant for most practical engineering problems (Fig. 1). The data shown in Figure 5 clearly indicate that stiffness measured externally is underestimated, especially for smaller values of modulus i.e. corresponding to smaller stress range. Additionally, it the difference would be much bigger. It is also worth to underline that the differences are more pronounced for dense or very stiff materials.

\section{RESONANT COLUMN AND CYCLIC TRIAXIAL TESTS}

In soil mechanics the terms static and dynamic modulus exists. Practicing geotechnical engineers have no doubts that for the same material and state the dy- 
namic modulus is higher than the static one. However if one account for strain range (Ishihara 1996) and drainage conditions, which are different for these two kinds of loading, this difference disappears. Therefore cyclic and dynamic tests are used not only in earthquake engineering or transient loading situation. For example cyclic triaxial tests are used for determination of modulus which is related to recoverable strain (elastic or quasi-elastic). In this kind of triaxial apparatus practically only loading system is different than in the static one. The cell and other parts of the apparatus are the same.

Entirely different situation is with resonant column. This is typical dynamic test. Amplitude and frequency of loading make possible testing only to a strain range not bigger $0.3 \%$. However this is enough when comparing to strain range of interest in engineering problems. With respect to strain range, resonant column seems to be a perfect equipment. However, it should be emphasized that the most common type of resonant column (fixed free) makes possible to applied only isotropic consolidation prior to actual resonant tests and there are some limitation in testing very soft soils. Unfortunately, it is quite often happen with beginner users of resonant column that they publish just raw results on material $\mathrm{X}$ as a scientific achievement. Meanwhile, there are ways to enhance capability of the equipment. One of example of such situation is shown in Figure 6, where two charts are shown. The data concern undisturbed high plas-
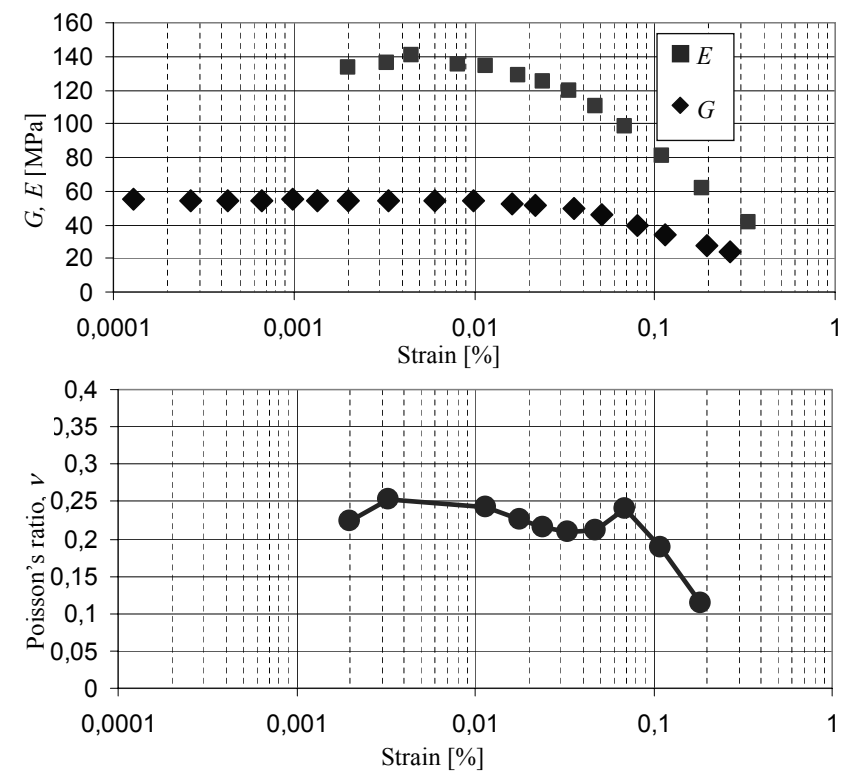

FIGURE 6. Distribution of stiffness and Poisson's ratio determined on the basis of cyclic triaxial and resonant column test results 
ticity clay sampled from foundation of the II line of Warsaw Metro. In the upper chart, distribution of two moduli against strain are shown. Deformation modulus $(E)$ was determined from cyclic triaxial test, while shear modulus $(G)$ was obtained on the basis of resonant column test. In order to compare these two moduli, strain obtained during triaxial tests $\left(\varepsilon_{a}\right)$ were converted to shear strain $\left(\varepsilon_{s}\right)$ with use of the formula derived from theory of elasticity:

$$
\varepsilon_{s}=\frac{2}{3}\left(\varepsilon_{v}-\varepsilon_{h}\right)
$$

The same theory relates two considered moduli as parameters describing elastic body. Since the formula contains the third (dependent) parameter i.e. Poisson's ratio $(v)$, it is possible to calculate it on the basis of two obtained directly from tests moduli from the following formula:

$$
v=\frac{1}{2} \frac{E}{G}-1
$$

Calculated values of Poisson's ratio (v) are shown in Figure 6 in the lower chart. This kind of approach offers certain advantages. The first one is that it makes possible to get parameter which is very often used in elastic and elasto-plastic analysis but is very rarely determined during test. The added value is also the fact that the calculated value of Poisson's ratio are shown against strain, what allows not only observe change of the parameter but also helps to deter- mine range of strain to which response of soil can be considered elastic or hypo-elastic. In the example shown in Figure 6 the elastic strain terminates at level $10^{-2 \%}$ and hypo-elastic range corresponds to $0.07 \%$. Certainly, if the test had been done on soil of low plasticity or on sand, these strain ranges would have been considerable smaller. The above example shows that those two kind of apparatuses used together have a certain potential for enhanced interpretation of the data.

\section{SHEAR WAVES VELOCITY MEASUREMENT}

Body wave velocity on soil samples have been measured in a laboratory for more than 50 years now (Hardin and Richart 1963). Piezoceramic transducers, and especially use of bender element (Shirley 1978) have contributed to common use of this kind of technique in geotechnical laboratories. Laboratory procedures for measurement and methods for proper identification of arriving signals improved with years (Lo Presti et al. 1995, Brignoli et al. 1996). If one wants to measure wave velocity in laboratory with relevant accuracy a commercially available equipment is not the only condition which must be fulfilled. A certain skill built on long experience is necessary to acquire knowledge concerning (among others) the following issues:

- what piezoelement (bender or shear plate) is better to use for various soils? 
- how to use filters for signal conditioning?

- how to select appropriate frequency?

- how does identification of signal change with stress increase?

Certainly the above hints concern shear wave velocity, since that kind of waves reflects quality of contact of grains and particles and therefore is easy converted to initial shear modulus $\left(G_{0}\right)$ with use of well known formula derived from theory of elasticity. However, even with use of commercially available apparatus, which usually is not equipped with separate piezoelements for longitudinal $(P)$ wave velocity, one can measure $P$-waves by generating signal with bender element. Apart from discussion whether such measurement is of the same quality as in case of separate piezoelements for $P$-waves, it is always seductive to calculate all parameters describing elastic body i.e. shear modulus $(G)$, deformation modulus $(E)$, bulk modulus $(K)$ and Poisson's ratio (v). However, it must be kept in mind that all those formulae for calculation of the above parameters were derived for one phase body and not for two (or even three) phases body as it is in case of soil. It is easy to check it by trying to calculate Poisson's ratio (v) on the basis of S\&P waves velocity measurement. Such calculations always deliver higher values (even twice) than the actual one (Fig. 6). In case of no possibility of doing cyclic triaxial and resonant column tests on soil sampled from the same place it is better to use triaxial test with internally measured deformation. This kind of measurement delivers quite reasonable results (Lipiński 2006, 2013).

Another issue associated with shear wave velocity for evaluation of initial stiffness is an accuracy and reliability of measurement. In case of natural soils it happens quite often that deformation modulus $(E)$ for very small strain (i.e. initial state corresponding to $10^{-5}-10^{-4 \%}$ ) does match the data from shearing for strain range $10^{-2}-10^{-1} \%$, even in the case when the modified cell is used. Although it cannot be excluded that an error originates from shearing data it is also conceivable that it is results from shear wave velocity measurement. The crucial issue in $V_{s}$ measurement is identification of arriving signal. A laboratory experience shows that possibility of error appearance is much higher when single measurement (prior to shearing) is done. A shape of signals substantially changes with stress and frequency. Therefore, it is advisable to make a shear wave velocity measurement at the end of each stage of consolidation. Stage consolidation is certainly more time consuming procedure but offers a major advantage which rests on possibility of tracing change of wave velocity form with stress increase. Smooth relation between shear wave velocity and stress can be a good criterion for verification of signal arrival time readings. It additionally allows to observe evolution of signal shape, what significantly 
increases credibility of actual time reading. This practice, although time consuming, is highly recommended not only in research laboratories but also for use in engineering practice.

The last but not least issue concerns quality of samples used for tests. It is especially refers to so called undisturbed samples. An experience concerning natural foundation soils, resting in comparison of in situ shear wave velocity with laboratory results, clearly indicates that stiffness determined in a laboratory is lower. This fact should always be taken into account in interpretation of the data for engineering purposes.

\section{SUMMARY AND CONLUSIONS}

Design of majority of structures, especially the bigger ones, are controlled by serviceability limit state. Stiffness of soil is a key issue in calculation of a subsoil deformation. Working range of strain most often encountered in engineering structures practically limits interest in stiffness determination to corresponding strain not exceeding $0.3 \%$. This fact has a consequence in increasing requirements concerning reliable measurement of stiffness parameters. In practice, various laboratory equipment is assigned to particular strain range. Capability of and limitations of the most popular equipment is described in the paper. Evolution of accuracy enhancement in stiffness determination is presented on the example of upgrading of triaxial apparatus i.e. standard cell, the one modified one and triaxial cell with internal measurement of strain. The reasons for why standard triaxial cell cannot be used for stiffness determination were clearly explained. System of internal measurement of specimen deformation accommodated with proximity transducers were presented. The results which prove underestimation of stiffness in case of external measurements of deformation are presented. The other set of data from cyclic triaxial tests and resonant column are combined in order to present the approach allowing to obtain Poisson's ratio distribution against strain. At the end, some remarks concerning measurement and interpretation of wave velocity measurement in the laboratory are given. Majority of these comments and conclusions are based on more than 25 years experience in enhancement of laboratory tests quality.

\section{REFERENCES}

ATKINSON J.H., SÄLLFORS G. 1991: Experimental determination of soil properties. Proc. $10^{\text {th }}$ EC on SMFE, Firenze 3, 915-956.

BALDI G., HIGHT D.W., THOMAS G.E. 1988: A reevaluation of conventional triaxial test methods. ASTM STP 977, 219-263

BARAŃSKI T., WOLSKI W. 1986: Lateral strain measurement by an ultrasonic method. Consolidation of soil: Testing and evaluation. . R.N. Yong and F.C. Townsend (Eds.). American Society for Testing and Materials, Philadelphia. ASTM STP 892, 516-525.

BRIGNOLI E., GOTTI M., STOKOE K.H. 1996: Measurement of shear waves in laboratory specimens by means of piezoelectric transducers. Geotechnical Testing Journal, ASTM, 19 (4), 607-613.

BURLAND J.B. 1989: Ninth Lauritis Bjerrum Memorial Lecture: Small is beautiful: the 
stiffness of soils at small strains. Canadian Geotechnical Journal 26 (4), 449-516.

HARDIN B.O., RICHART F.E. JR. 1963: Elastic wave velocity in granular soils. Proc. ASCE 89 (SH1), 33-65.

ISHIHARA K. 1996: Soil Behaviour in Earthquake Engineering. Clarendon Press, Oxford.

JAMIOLKOWSKI M., LANCELLOTTA R., Lo PRESTI D.C.F., PALLARA O. 1994: Stiffness of Toyoura sand at small and intermediate strain. Proc. XIII ICSMFE, New Delhi, Oxford \& IBH Publishing Co., PVT. Ltd, Vol. $1,169-172$.

JARDINE R.J., SYMES M.J., BURLAND J.B. 1984: The measurement of soil stiffness in the triaxial apparatus. Geotechnique 34 (3), 323-340.

LIPIŃSKI M.J. 2006: Małe... ale jak bardzo istotne. Zeszyty Naukowe Politechniki Biatostockiej. Budownictwo 28 (1), 191-200.

LIPIŃSKI M.J. 2012: Wybrane kryteria określania parametrów gruntów naturalnych. Inżynieria Morska i Geotechnika 4, 267-277.

LIPIŃSKI M.J. 2013: Kryteria wyznaczania parametrów geotechnicznych. Wydawnictwo SGGW, Warszawa.

Lo PRESTI D.C.F., FROST J.D., SCHOLEY G.K., JAMIOLKOWSKI M. 1995: A review of instrumentation for measuring small strains during triaxial testing of soil specimens. Geotechnical Testing Journal, GTJODJ 18 (2).

MAIR R.J. 1993: Development in geotechnical engineering research: application to tunnels and deep excavations. Proc. of the Institution of Civil Engineers, Unwin Memorial Lecture 1992. Civil Engineering 93, 27-41.

SCHOLEY G.K., FROST J.D., Lo PRESTI D.C.F., JAMIOLKOWSKI M. 1995: A review of instrumentation for measuring small strains during triaxial testing of soil specimens. Geotechnical Testing Journal, GTJODJ 18 (2), 137-156.
SHIRLEY E.T. 1978: An improved shear wave transducer. Journal of Acoustical Society of America 63, 1643-1645.

Streszczenie: Możliwości i ograniczenia wyznaczania sztywności gruntu metodami laboratoryjnymi. Artykuł dotyczy laboratoryjnych metod wyznaczania sztywności gruntu. Głównym kryterium dla wyboru omawianej aparatury jest zakres odkształcenia, w którym wartości modułów moga być wyznaczane w sposób wiarygodny. Zasadniczo omawiane są różne wersje aparatów trójosiowych, tzn. z komorą standardową i komorą zmodyfikowaną. Dodatkowo omówiono system do wewnątrzkomorowego pomiaru przemieszczeń próbki oraz przedstawiono przesłanki do jego zastosowania, ilustrując to wynikami badań własnych. Omówiono również pomiary prędkości fal poprzecznych jako narzędzie do określania początkowej sztywności. Przedstawiono wymagania dotyczące poprawności pomiaru, jak również interpretacji wyniku. Na koniec przedstawiono podejście do określania rozkładu współczynnika Poissona w zależności od odkształcenia przy wykorzystaniu wyników badań w cyklicznym aparacie trójosiowym i kolumnie rezonansowej.

Słowa kluczowe: parametry sztywności gruntu, zakres małych i średnich odkształceń, badania laboratoryjne

\section{MS. received May 2015}

\section{Authors' address:}

Mirosław J. Lipiński, Małgorzata K. Wdowska Wydział Budownictwa i Inżynierii Środowiska SGGW

Katedra Geoinżynierii

ul. Nowoursynowska 159, 02-776 Warszawa

Poland

e-mail: miroslaw_lipinski@sggw.pl malgorzata_wdowska@sggw.pl 